\title{
A call to action for climate change research on Caribbean dry forests
}

\author{
Howard P. Nelson ${ }^{1} \cdot$ Eleanor S. Devenish-Nelson ${ }^{1} \cdot$ Bonnie L. Rusk ${ }^{2} \cdot$ Matt Geary $^{1} \cdot$ Andrew J. Lawrence ${ }^{1}$
}

Received: 30 January 2018 / Accepted: 4 April 2018 / Published online: 20 April 2018

(C) The Author(s) 2018

\begin{abstract}
Tropical dry forest (TDF) is globally one of the most threatened forest types. In the insular Caribbean, limited land area and high population pressure have resulted in the loss of over $60 \%$ of TDF, yet local people's reliance on these systems for ecosystem services is high. Given the sensitivity of TDF to shifts in precipitation regimes and the vulnerability of the Caribbean to climate change, this study examined what is currently known about the impacts of climate change on TDF in the region. A systematic review $(n=89)$ revealed that only two studies addressed the ecological response of TDF to climate change. Compared to the rapidly increasing knowledge of the effects of climate change on other Caribbean systems and on TDF in the wider neotropics, this paucity is alarming given the value of these forests. We stress the need for long-term monitoring of climate change responses of these critical ecosystems, including phenological and hotspot analyses as priorities.
\end{abstract}

Keywords Adaptation $\cdot$ Ecosystem services $\cdot$ Small island developing states $\cdot$ Vulnerability

\section{Introduction}

Small island developing states (SIDS) are known to be particularly at risk to the impacts of climate change, yet current understanding of environmental responses to climate change for small islands is woefully lacking (Duvat et al. 2017). This

Editor: Jamie Pittock

Electronic supplementary material The online version of this article (https://doi.org/10.1007/s10113-018-1334-6) contains supplementary material, which is available to authorized users.

Howard P. Nelson

h.nelson@chester.ac.uk

Eleanor S. Devenish-Nelson

e.devenishnelson@chester.ac.uk

Bonnie L. Rusk

blrusk1@gmail.com

Matt Geary

m.geary@chester.ac.uk

Andrew J. Lawrence

a.lawrence@chester.ac.uk

1 Department of Biological Sciences, University of Chester, Parkgate Road, Chester CH2 3BL, UK

2 Grenada Dove Conservation Programme, St. Georges, West Indies, Grenada is of concern, given the often unique island ecosystems and that data deficiency can reduce the success of adaptation actions and decision-making processes on these islands (Mycoo et al. 2017; Robinson 2017).

Tropical dry forest (TDF) has long received less research effort than humid forest (Blackie et al. 2014). However, evidence is growing globally of the value of their ecosystem services (Portillo-Quintero et al. 2015) and their degree of endangerment (Banda et al. 2016). Ecosystem services of TDF are vital for local communities (Portillo-Quintero et al. 2015). For example, TDF provides carbon storage worth US\$262,000 annually on the island of St Eustatius (Tieskens et al. 2014b), recreational value of over US\$30,000 on Saba (Tieskens et al. 2014a) and US\$17,000,000 in pollination and seed dispersal services on Bonaire (Cortes 2012). However, the impact of climate change on TDFs has received less attention than other forest types (Blackie et al. 2014), yet TDFs are especially sensitive to drying conditions and increased water stress can result in increased mortality (Brienen et al. 2010). A key factor limiting development of the plausible future scenarios needed for robust forest management is poor understanding of ecological response to climate change (Keenan 2015).

Despite having previously lost much of its TDF ( $>60 \%)$, the insular Caribbean still hosts over 9\% of Neotropical TDF, though most of this $(>80 \%)$ is highly fragmented (PortilloQuintero and Sánchez-Azofeifa 2010). Physiognomically and 
floristically, this insular TDF is distinct from continental Neotropical TDF (Banda et al. 2016; Murphy and Lugo 1995), with its high species-level endemism (LinaresPalomino et al. 2011; Maunder et al. 2011) making the region's TDF of particular conservation value. The anthropogenic pressures faced by these insular forests are also distinctive from continental TDF (Portillo-Quintero and SánchezAzofeifa 2010). Specifically, Caribbean TDF is often dominated by invasive species (Ramjohn et al. 2012; Wolfe and van Bloem 2012) and located in lowland areas subject to intense development pressure (Portillo-Quintero and SánchezAzofeifa 2010). In the Caribbean SIDS, climate change is increasingly well-documented, with decreasing precipitation predicted (Karmalkar et al. 2013). To future-proof TDF against climate change, it is necessary to understand the potential ecological impacts on these unique forest systems. Here, a systematic review quantifies current understanding of climate change impacts on TDF in the insular Caribbean.

\section{Methods}

The systematic review methodology was based on wellestablished guidelines (Pullin and Stewart 2006). Boolean searches were conducted in Web of Knowledge from January 1981 to August 2017, for the phrases ["Caribbean"] AND ["dry forest"], AND ["climat* change" OR "global warming"]. A search was also performed using scholar.google.com, with the first 100 documents examined for their inclusion suitability. Grey literature databases were also searched (Food and Agriculture Organisation, Treesearch and Caribbean Community Climate Change Centre) and additional literature identified through in-text citations of search results.

This review addressed the question: what are the ecological impacts of climate change in insular Caribbean TDFs? Studies were assessed using specified inclusion/exclusion criteria for study type, subject, outcome and geographic location (Supplementary Table 1).

\section{Results}

Eighty-nine sources of literature were identified from all searches. Of these, 10 were excluded based on study type, 31 for not meeting subject criteria and 27 due to their geographic location. Twenty-one qualified as potentially addressing the question. After a full review of these studies, three were excluded based on the study outcome criteria, five because of the geographic focus, three for failing to meet subject criteria and one for study type. Only two studies referenced specific ecological responses of TDF to climate change, all published since 2016 and both from Puerto Rico. These two papers presented future predictions of TDF distribution and changes in biomass due to increased hurricane activity, respectively. The remaining eight papers provided evidence related to climatic drivers of TDF, but the study aims were not explicitly related to climate change. Of these studies, three presented data on the structural response of TDF to hurricanes, one on the climatic drivers of fire and three on climate-driven species composition or phenology trends.

\section{Discussion}

That this review found only two studies of the ecological impacts of climate change on Caribbean TDF highlights our poor understanding of the response of these forest systems to climate change. This is deeply troubling and is in contrast to increasing research on climate change impacts on other Caribbean ecosystems, such as beach and coral reef habitats (Cambers 2009; Randall and Van Woesik 2015) and other forest types (McKee et al. 2007; Scatena 1998). Similarly, this contrasts to increasing climate change research on continental Neotropical dry forests (Aguirre et al. 2017; Brienen et al. 2010; Prieto-Torres et al. 2016).

\section{What do we know?}

Exposure to climate change in the Caribbean is expected to include a $2-5^{\circ} \mathrm{C}$ increase in air temperature by the $2080 \mathrm{~s}$, with drying of 20-40\% expected, particularly during the wet season (Karmalkar et al. 2013). In addition, hurricanes are predicted to become more intense under certain climate scenarios (Grinsted et al. 2013).

Climatic drivers of Caribbean TDF compositional and demographic patterns are relatively well-studied (e.g. Brandeis et al. (2009); Rojas-Sandoval and Meléndez-Ackerman (2011); Van Bloem et al. (2006)). Since TDF dynamics are particularly sensitive to precipitation (Murphy and Lugo 1995), increased drought severity will likely reduce growth and reproductive effort (Rojas-Sandoval and MeléndezAckerman 2011) or change species composition (Brandeis et al. 2009). On Puerto Rico, models predict an island-wide shift from moist to dry life zones due to reduced precipitation and increased temperatures, with the replacement of subtropical dry forest by dry forest by 2099 (Khalyani et al. 2016). However, models did not account for unfavourable future land-use constraining suitable conditions. Hurricanes are key modifiers of Caribbean TDF structure and although these forests are resilient (Van Bloem et al. 2006), recovery from severe events can take decades (Imbert and Portecop 2008). Modelling of Puerto Rican TDF suggests that increased hurricane frequency, but not intensity, would lead to a sustained decrease in carbon stock (Holm et al. 2017). 
Our understanding of anthropogenic drivers of Caribbean TDF (e.g. Ramjohn et al. (2012); Wolfe and van Bloem (2012)) provides insight into TDF vulnerability and adaptive capacity to climate change. Anthropogenic fire results in long post-disturbance recovery times for Caribbean TDF (Wolfe and van Bloem 2012) and fire is known to increase with rising minimum daily temperatures and declining precipitation (Monmany et al. 2017). Invasive species are dominant in many Caribbean TDF, particularly those recovering from disturbance (Ramjohn et al. 2012). While the ecological outcome of novel communities is debated and may not be negative (Lugo 2004), some invasive species are highly drought- and fire-resistant (Wolfe and van Bloem 2012), in contrast to many native species.

While current understanding is valuable for making inferences about climate change impacts on Caribbean TDF, predicting system responses requires a deeper understanding of species- and community-level sensitivity and exposure (Williams et al. 2008). Ideally, this involves integrating experimental and gradient methods to determine both large-scale and mechanistic climate-ecosystem interactions (Dunne et al. 2004). Achieving such insight demands a research framework that includes predictive models, experiments and management-relevant data collection.

\section{Current limitations for climate change research}

A significant challenge for research on the ecological impacts of climate change on Caribbean forests is the lack of data to parameterise models and inform management. Such data limitations include:

- Inconsistent and inaccessible historical meteorological data (Lumbroso et al. 2011), while future climate projections lack the spatial resolution required for accurate predictions on topographically complex, small islands (Maharaj and New 2013)

- Landscape-level species occurrence data are patchy across the region and long-term monitoring is inconsistent. Permanent plots, such as those set up by the FAO Tropical Forestry Action Programme in the 1980s, are often infrequently re-visited due to a lack of manpower and resources and loss of institutional memory.

- Long-term field or laboratory experiments on survival and growth exist for few TDF species or locations (McLaren et al. 2011) and species-specific trait data across environmental gradients is limited to a few well-studied systems (e.g. Brandeis et al. (2009)).

- Little is known about potential changes in hydrological processes and consequences of rainfall patterns for tree growth (Farrick and Branfireun 2013).

- Few island-specific spatial predictions of future land-use change exist (Newman et al. 2014).
In the Caribbean SIDS, the reality is that research is limited by financial, political, capacity and logistical constraints (Kaiser-Bunbury et al. 2015). It is no surprise that the island with the greatest research effort (Puerto Rico) has external support (International Institute for Tropical Forestry of the US Forest Service). While emphasising the need to focus research on Caribbean TDF, we advocate an integrative and interdisciplinary approach. Any regional research framework must take a 'least cost' approach and enable a clear link between on-the-ground adaptation actions and species responses.

\section{What are future research priorities?}

Our recommendations for work on TDF climate response are not exhaustive (Table 1), but are chosen to complement priorities already identified for dry forest (Banda-Rodriquez et al. 2016) and forestry more widely in the Caribbean (Gonzalez and Heartsill Scalley 2016), as well as consider regional financial and capacity challenges.

Understanding the potential change in TDF distribution requires an understanding of all forest types at the leading and trailing TDF edges. The steep climatic gradients on many Caribbean islands (Murphy and Lugo 1995) add a layer of complexity when predicting the ecosystem response to climate change. Identifying a small number of region-wide species to monitor is a priority for understanding species responses across such gradients. For this to succeed, overcoming the challenge of long-term monitoring demands putting more onus on the researcher to engage local practitioners (Kaiser-Bunbury et al. 2015).

Models provide meaningful insight into the management and a physiological framework of species responses to climatic changes (Williams et al. 2008). Recent models of Puerto Rican TDF (Holm et al. 2017; Khalyani et al. 2016) demonstrate the value of such approaches. Long-term vegetation monitoring together with monitoring key climatic variables is an important step in understanding the sensitivity of Caribbean TDF to climate change impacts. Importantly, improving climate data collection would benefit all aspects of climate change research across all habitats in the region.

Predicting future change in TDF distribution and developing climate change adaptation requires evaluating landscapescale patterns in forest cover, especially those driven by region-specific anthropogenic factors such as urbanisation. A lack of technological capacity has to date hindered the data analysis required for improved decision-making related to complex land tenure in the Caribbean (Mycoo et al. 2017), which increases the vulnerability of TDF to climate change and the ability to adapt (Medeiros et al. 2011). Recent efforts elucidating temporal land-use change in Jamaica from spatially explicitly models (Newman et al. 2014) and innovative emerging technology, such as Caribbean-wide crowdsourced 
Table 1 Priority research areas of ecological climate change impacts on Caribbean TDF

\begin{tabular}{|c|c|c|c|c|}
\hline $\begin{array}{l}\text { Research } \\
\text { area }\end{array}$ & Description & Examples in Caribbean & Justification & Ease of implementation \\
\hline $\begin{array}{l}\text { Hotspot } \\
\text { analysis }\end{array}$ & $\begin{array}{l}\text { Mapping of fire and } \\
\text { invasive species risk }\end{array}$ & $\begin{array}{l}\text { Predictive models of fire risk } \\
\text { for Puerto Rico (Monmany et al. } \\
\text { 2017) }\end{array}$ & $\begin{array}{l}\text { Pertinent for spatial } \\
\text { prioritisation of management } \\
\text { and adaptation actions, } \\
\text { vulnerability }\end{array}$ & $\begin{array}{l}\text { Initial analysis could be conducted } \\
\text { using existing open access data } \\
\text { (e.g. Moderate Resolution Imaging } \\
\text { Spectroradiometer - MODIS } \\
\text { imagery and the Global Biodiversity } \\
\text { Information Facility - GBIF) }\end{array}$ \\
\hline Phenology & $\begin{array}{l}\text { Long-term monitoring } \\
\text { timing of seasonal } \\
\text { life-cycle events }\end{array}$ & $\begin{array}{l}\text { Puerto Rico is already participating } \\
\text { in the PhenoCam network } \\
\text { (phenocam.sr.unh.edu) }\end{array}$ & $\begin{array}{l}\text { Invaluable for understanding } \\
\text { species (e.g. endemic, } \\
\text { invasive) sensitivity and } \\
\text { adaptive capacity }\end{array}$ & $\begin{array}{l}\text { Expanding the PhenoCam network is a } \\
\text { relatively cost-effective, low } \\
\text { personnel commitment }\end{array}$ \\
\hline $\begin{array}{r}\text { Ecosystem } \\
\text { services }\end{array}$ & $\begin{array}{l}\text { Mapping and total } \\
\text { economic valuation } \\
\text { (TEV) of ecosystem } \\
\text { services }\end{array}$ & $\begin{array}{l}\text { TEV model of current TDF value in } \\
\text { Bonaire (Cortes 2012) }\end{array}$ & $\begin{array}{l}\text { Promotes political and civil } \\
\text { society buy-in of the } \\
\text { importance of climate change } \\
\text { adaptation }\end{array}$ & $\begin{array}{l}\text { Methods to incorporate economic } \\
\text { costs/benefits of climate change } \\
\text { can be data-hungry }\end{array}$ \\
\hline $\begin{array}{l}\text { Long-term } \\
\text { monitoring }\end{array}$ & $\begin{array}{l}\text { Species-specific responses } \\
\text { and changes in forest } \\
\text { structure and } \\
\text { composition caused by } \\
\text { climate and disturbance }\end{array}$ & $\begin{array}{l}\text { Recent proposals for a Caribbean } \\
\text { permanent plot network (Gonzalez } \\
\text { and Heartsill Scalley 2016). Rainfor } \\
\text { (Red Amazónica de Inventarios } \\
\text { Forestales) permanent plot network, } \\
\text { part of the global ForestPlots.Net } \\
\text { initiative provides a useful model. }\end{array}$ & $\begin{array}{l}\text { Multiple potential data uses, e.g. } \\
\text { space-for-time, climate } \\
\text { gradients, physiological } \\
\text { responses, introduced vs. } \\
\text { native species, endemic } \\
\text { species, ecosystem services } \\
\text { and early warning systems, } \\
\text { sensitivity, exposure and } \\
\text { adaptive capacity }\end{array}$ & $\begin{array}{l}\text { Costly and logistically challenging } \\
\text { long-term permanent plots and } \\
\text { experimental approaches }\end{array}$ \\
\hline Modelling & $\begin{array}{l}\text { Ecological niche, } \\
\text { trait-based, and } \\
\text { mechanistic models of } \\
\text { species responses to } \\
\text { climate change; } \\
\text { interpolation of } \\
\text { climatic variables; } \\
\text { spatially explicit } \\
\text { land-use change } \\
\text { models }\end{array}$ & $\begin{array}{l}\text { Ecological niche model of selected } \\
\text { tropical moist forest species on } \\
\text { Trinidad (Maharaj and New 2013); } \\
\text { mechanistic models of future } \\
\text { hurricane on Puerto Rico (Holm et al. } \\
\text { 2017); kriging used to interpolate } \\
\text { climate for mapping Holdridge life } \\
\text { zones on PuertoRico (Khalyani et al. } \\
\text { 2016) }\end{array}$ & $\begin{array}{l}\text { Species sensitivity and } \\
\text { exposure, drivers of land-use } \\
\text { change, scenario and land-use } \\
\text { planning, protected areas, } \\
\text { agriculture and tourism, } \\
\text { physiological understanding } \\
\text { of species responses }\end{array}$ & $\begin{array}{l}\text { Niche-based and interpolation models } \\
\text { less data-hungry than more robust } \\
\text { mechanistic models }\end{array}$ \\
\hline
\end{tabular}

All identified research areas are considered of equal priority

land-use/land-cover imagery (Clark and Aide 2011), offer potential options for future work in this area.

Economic valuation provides a means to integrate the socioeconomic benefits of TDF into climate change adaptation. Lessons learned from the success of translating Caribbean coastal economic valuations into decision-making highlight the importance of informed and collaborative stakeholder engagement (Waite et al. 2015). Given the close relationship between forest management and agriculture, tourism and land-use planning, promoting inter-sectoral synergies is vital for realising the full potential of a region-wide, TDF research strategy.

The impacts of climate change on Caribbean TDF will be far reaching. An improved understanding of these research priorities is of relevance not only for the conservation of these unique forests but also for climate change adaptation in economic sectors, such as tourism and agriculture. Indeed, a robust scientific framework is a specific recommended component of the multi-stage climate change adaptation planning recommended for SIDS to meet their 2030 Sustainable Development Goals, and a widely recognised catalyst for achieving climate change adaptation (Robinson 2017).
Acknowledgements We thank Anthony Jeremiah, Chief Forestry Officer, Government of Grenada, for logistical support and feedback on the manuscript and two anonymous reviewers for constructive comments. Funding information This study was funded by the Critical Ecosystem Partnership Fund (\#64202).

Open Access This article is distributed under the terms of the Creative Commons Attribution 4.0 International License (http:// creativecommons.org/licenses/by/4.0/), which permits unrestricted use, distribution, and reproduction in any medium, provided you give appropriate credit to the original author(s) and the source, provide a link to the Creative Commons license, and indicate if changes were made.

\section{References}

Aguirre N, Eguiguren P, Maita J, Ojeda T, Sanamiego N, Furniss M, Aguirre Z (2017) Potential impacts to dry forest species distribution under two climate change scenarios in southern Ecuador. Neotrop Biodivers 3:18-29. https://doi.org/10.1080/23766808.2016.1258867

Banda K, Delgado-Salinas A, Dexter KG, Linares-Palomino R, OliveiraFilho A, Prado D, Pullan M, Quintana C, Riina R, Rodríguez GM (2016) Plant diversity patterns in neotropical dry forests and their conservation implications. Science 353:1383-1387. https://doi.org/ 10.1126/science.aaf5080 
Banda-Rodriquez K, Weintritt J, Pennington RT (2016) Caribbean dry forest networking: an opportunity for conservation. Caribb Nat Special Issue 1:63-72

Blackie R, Baldauf C, Gautier D, Gumbo D, Kassa H, Parthasarathy N, Paumgarten F, Sola P, Pulla S, Waeber P, Sunderland T (2014) Tropical dry forests: the state of global knowledge and recommendations for future research. Vol 2. CIFOR, Bogor, Indonesia

Brandeis TJ, Helmer EH, Marcano-Vega H, Lugo AE (2009) Climate shapes the novel plant communities that form after deforestation in Puerto Rico and the U.S. Virgin Islands. For Ecol Manag 258:1704 1718. https://doi.org/10.1016/j.foreco.2009.07.030

Brienen RJW, Lebrija-Trejos E, Zuidema PA, Martinez-Ramos M (2010) Climate-growth analysis for a Mexican dry forest tree shows strong impact of sea surface temperatures and predicts future growth declines. Glob Change Biol 16:2001-2012. https://doi.org/10.1111/j. 1365-2486.2009.02059.x

Cambers G (2009) Caribbean beach changes and climate change adaptation. Aquat Ecosyst Health Manag 12:168-176. https://doi.org/10. 1080/14634980902907987

Clark ML, Aide TM (2011) Virtual interpretation of Earth Web-Interface Tool (VIEW-IT) for collecting land-use/land-cover reference data. Remote Sens 3:601-620

Cortes DZ (2012) An ecological-economic model of the tropical dry forest on the island of Bonaire. MSc, Vrije Universiteit, Amsterdam

Dunne JA, Saleska SR, Fischer ML, Harte J (2004) Intregrating experimental and gradient methods in ecological climate change research. Ecology 85:904-916. https://doi.org/10.1890/03-8003

Duvat VKE, Magnan AK, Wise RM, Hay JE, Fazey I, Hinkel J, Stojanovic T, Yamano H, Ballu V (2017) Trajectories of exposure and vulnerability of small islands to climate change. Wiley Interdiscip Rev Clim Chang 8:e478. https://doi.org/10.1002/wcc. 478

Farrick KK, Branfireun BA (2013) Left high and dry: a call to action for increased hydrological research in tropical dry forests. Hydrol Process 27:3254-3262. https://doi.org/10.1002/hyp.9935

Gonzalez G, Heartsill Scalley T (2016) Building a collaborative network to understand regional forest dynamics and advance forestry initiatives in the Caribbean. Caribb Nat Special Issue 1:245-256

Grinsted A, Moore JC, Jevrejeva S (2013) Projected Atlantic hurricane surge threat from rising temperatures. Proc Natl Acad Sci 110:53695373. https://doi.org/10.1073/pnas.1209980110

Holm JA, Van Bloem SJ, Larocque GR, Shugart HH (2017) Shifts in biomass and productivity for a subtropical dry forest in response to simulated elevated hurricane disturbances. Environ Res Lett 12: 025007. https://doi.org/10.1088/1748-9326/aa583c

Imbert D, Portecop J (2008) Hurricane disturbance and forest resilience: assessing structural vs. functional changes in a Caribbean dry forest. For Ecol Manag 255:3494-3501. https://doi.org/10.1016/j.foreco. 2008.02.030

Kaiser-Bunbury CN, Fleischer-Dogley F, Dogley D, Bunbury N (2015) Scientists' responsibilities towards evidence-based conservation in a Small Island Developing State. J Appl Ecol 52:7-11. https://doi.org/ 10.1111/1365-2664.12346

Karmalkar AV, Taylor MA, Campbell JD, Stephenson T, New M, Centella A, Benzanilla A, Charlery J (2013) A review of observed and projected changes in climate for the islands in the Caribbean. Atmosfera 26:283-309. https://doi.org/10.1016/S0187-6236(13) 71076-2

Keenan RJ (2015) Climate change impacts and adaptation in forest management: a review. Ann For Sci 72:145-167. https://doi.org/10. 1007/s13595-014-0446-5

Khalyani AH, Gould WA, Harmsen E, Terando A, Quinones M, Collazo JA (2016) Climate change implications for Tropical Islands: interpolating and interpreting statistically downscaled GCM projections for management and planning. J Appl Meteorol 55:265-282. https:// doi.org/10.1175/JAMC-D-15-0182.1
Linares-Palomino R, Oliveira-Filho AT, Pennington RT (2011) Neotropical seasonally dry forests: diversity, endemism, and biogeography of woody plants. In: Seasonally dry tropical forests. Springer, pp 3-21

Lugo AE (2004) The outcome of alien tree invasions in Puerto Rico. Front Ecol Environ 2:265-273. https://doi.org/10.1890/ 1540-9295(2004)002[0265:TOOATI]2.0.CO;2

Lumbroso D, Boyce S, Bast H, Walmsley N (2011) The challenges of developing rainfall intensity-duration-frequency curves and national flood hazard maps for the Caribbean. J Flood Risk Manag 4:4252. https://doi.org/10.1111/j.1753-318X.2010.01088.x

Maharaj SS, New M (2013) Modelling individual and collective species responses to climate change within Small Island States. Biol Conserv 167:283-291. https://doi.org/10.1016/j.biocon.2013.08.027

Maunder M, Abdo M, Berazain R, Clubbe C, Jiménez F, Leiva A, Santiago-Valentín E, Jestrow B, Francisco-Ortega J (2011) The plants of the Caribbean islands: a review of the biogeography, diversity and conservation of a storm-battered biodiversity hotspot. In: Bramwell D, Caujapé-Castells J (eds) The biology of island floras. Cambridge University Press, Cambridge, pp 154-178

McKee KL, Cahoon DR, Feller IC (2007) Caribbean mangroves adjust to rising sea level through biotic controls on change in soil elevation. Glob Ecol Biogeogr 16:545-556. https://doi.org/10.1111/j.14668238.2007.00317.x

McLaren KP, Lévesque M, Sharma C, Wilson B, McDonald MA (2011) From seedlings to trees: using ontogenetic models of growth and survivorship to assess long-term ( $>100$ years) dynamics of a neotropical dry forest. For Ecol Manag 262:916-930. https://doi.org/10. 1016/j.foreco.2011.05.022

Medeiros D, Hove H, Keller M, Echeverría D, Parry J-E (2011) Review of current and planned adaptation action: the Caribbean. International Institute for Sustainable Development

Monmany AC, Gould WA, Andrade-Núñez MJ, González G, Quiñones $M$ (2017) Characterizing predictability of fire occurrence in tropical forests and grasslands: the case of Puerto Rico. In: Chakravarty S, Shukla G (eds) Forest ecology and conservation. InTechOpen, pp 77-95. doi:https://doi.org/10.5772/67667

Murphy PG, Lugo AE (1995) Dry forests of central America and the Caribbean. In: Bullock SH, Mooney HA, Medina E (eds) Seasonally dry tropical forests. University of Cambridge, Cambridge, pp 9-34

Mycoo MA, Griffith-Charles C, Lalloo S (2017) Land management and environmental change in small-island-developing states: the case of St. Lucia. Reg Environ Chang 17:1065-1076. https://doi.org/10. 1007/s10113-016-1050-Z

Newman ME, McLaren KP, Wilson BS (2014) Long-term socio-economic and spatial pattern drivers of land cover change in a Caribbean tropical moist forest, the Cockpit Country, Jamaica. Agric Ecosyst Environ 186:185-200. https://doi.org/10.1016/j.agee.2014.01.030

Portillo-Quintero CA, Sánchez-Azofeifa GA (2010) Extent and conservation of tropical dry forests in the Americas. Biol Conserv 143: 144-155. https://doi.org/10.1016/j.biocon.2009.09.020

Portillo-Quintero C, Sanchez-Azofeifa A, Calvo-Alvarado J, Quesada M, do Espirito Santo MM (2015) The role of tropical dry forests for biodiversity, carbon and water conservation in the neotropics: lessons learned and opportunities for its sustainable management. Reg Environ Chang 15:1039-1049. https://doi.org/10.1007/s10113-0140689-6

Prieto-Torres DA, Navarro-Sigüenza AG, Santiago-Alarcon D, RojasSoto OR (2016) Response of the endangered tropical dry forests to climate change and the role of Mexican Protected Areas for their conservation. Glob Change Biol 22:364-379. https://doi.org/10. $1111 /$ gcb. 13090

Pullin AS, Stewart GB (2006) Guidelines for systematic review in conservation and environmental management. Conserv Biol 20:16471656. https://doi.org/10.1111/j.1523-1739.2006.00485.x 
Ramjohn IA, Murphy PG, Burton TM, Lugo AE (2012) Survival and rebound of Antillean dry forests: role of forest fragments. For Ecol Manag 284:124-132. https://doi.org/10.1016/j.foreco.2012.08.001

Randall C, Van Woesik R (2015) Contemporary white-band disease in Caribbean corals driven by climate change. Nat Clim Chang 5:375379. https://doi.org/10.1038/nclimate2530

Robinson S-A (2017) Climate change adaptation trends in small island developing states. Mitig Adapt Strat G1 22:669-691. https://doi.org/ 10.1007/s11027-015-9693-5

Rojas-Sandoval J, Meléndez-Ackerman E (2011) Reproductive phenology of the Caribbean cactus Harrisia portoricensis: rainfall and temperature associations. Botany 89:861-871. https://doi.org/10.1139/ b11-072

Scatena F An assessment of climate change in the Luquillo Mountains of Puerto Rico. In: Third International Symposium on Water Resources, San Juan, Puerto Rico. American Water Resources Association, Washington, DC, 1998. pp 193-198

Tieskens K, Schep S, van Beukering P, van Beek I, Wolfs E (2014a) Mapping the economic value of ecosystems on Saba. Institute for Environmental Studies, Amsterdam
Tieskens K, Schep S, van Beukering P, van Beek I, Wolfs E (2014b) Mapping the economic value of ecosystems on St Eustatius. Institute for Environmental Studies, Amsterdam

Van Bloem SJ, Lugo AE, Murphy PG (2006) Structural response of Caribbean dry forests to hurricane winds: a case study from Guanica Forest, Puerto Rico. J Biogeogr 33:517-523. https://doi. org/10.1111/j.1365-2699.2005.01450.x

Waite R, Kushner B, Jungwiwattanaporn M, Gray E, Burke L (2015) Use of coastal economic valuation in decision making in the Caribbean: enabling conditions and lessons learned. Ecosyst Serv 11:45-55. https://doi.org/10.1016/j.ecoser.2014.07.010

Williams SE, Shoo LP, Isaac JL, Hoffman AA, Langham G (2008) Towards an integrated framework for assessing the vulnerability of species to climate change. PLoS Biol 6:e325-e2626. https://doi.org/ 10.1371/journal.pbio.0060325

Wolfe BT, van Bloem SJ (2012) Subtropical dry forest regeneration in grass-invaded areas of Puerto Rico: understanding why Leucaena leucocephala dominates and native species fail. For Ecol Manag 267:253-261. https://doi.org/10.1016/j.foreco.2011.12.015 